\title{
Like Nothing
}

\author{
Martha Townsend
}

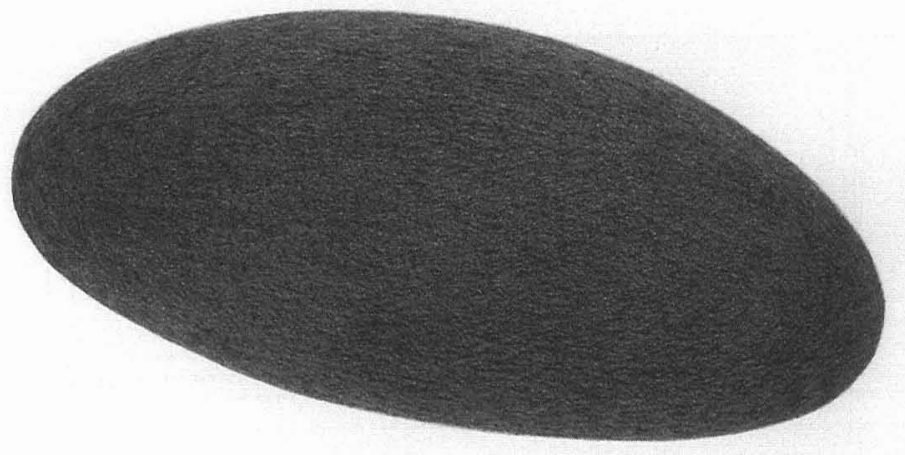

Like Nothing 9, 1999, graphite on Arches, $18 \mathrm{~cm} \times 26 \mathrm{~cm}$

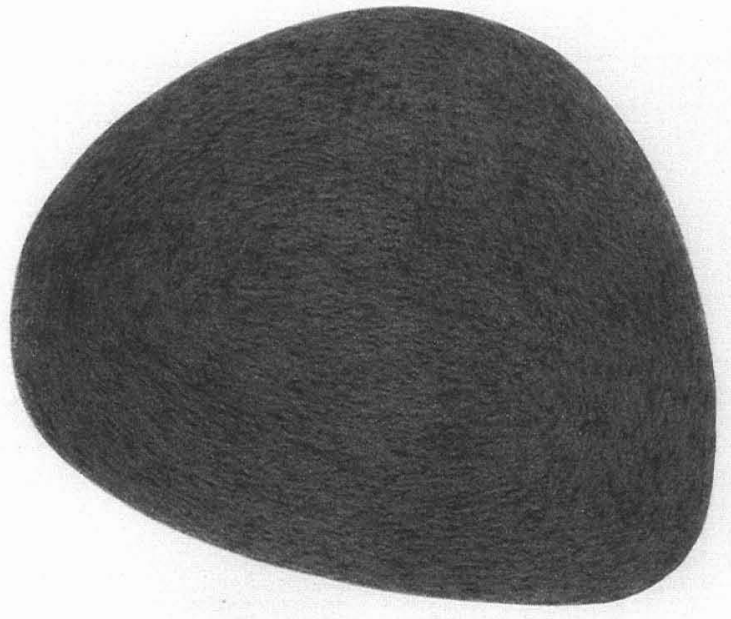



Like Nothing 12, 1999, graphite on Arches, $18 \mathrm{~cm} \times 26 \mathrm{~cm}$ 